\title{
Synthesis, In Vitro Evaluation of Some Novel Quinazolin- 4(3H)-one Derivatives as Anti-Tumor Agents
}

\author{
K. SRIVALLI* and K. SATISH
}

Department of Pharmaceutical Chemistry, Bharat Institute of Technology (Pharmacy), Ibrahimpatnam, Hyderabad, Andhra Pradesh, India

srivalli.pharmacy@gmail.com

Received 21 June 2012 / Accepted 8 July 2012

\begin{abstract}
In an effort to develop anticancer agents, a series of Mannich bases were prepared by Mannich reaction. When one biologically active molecule is linked to another, the resultant molecule generally has increased potency. Hence two pharmacophores, i.e. quinazoline ring and amine moiety are fused to obtain highly potent, more specific and less toxic agent. In the present study, synthesis of novel quinazolin-4(3H)-one derivatives by condensation of appropriate quinazolines with various $p$ substituted primary amines in presence of glacial acetic acid and ethanol at room temperature (Mannich reaction). Synthesized compounds were characterized; both analytical and spectral data (UV, IR, GC-MS, ${ }^{1} \mathrm{H}$ NMR) of all derivatives were in full agreement with proposed structures. All the derivatives were tested for their anti-tumor activity by two in vitro studies like Brine shrimp Lethality assay and Trypan blue exclusion assay.
\end{abstract}

Keywords: Quinazolinones, Mannich reaction, Brine shrimp lethality assay, Trypan blue exclusion assay

\section{Introduction}

The search for new anticancer agent is one of the most challenging tasks to the medicinal chemist. Heterocyclic compounds are biologically important class of compounds. This prompted us to synthesize hybrid analogues of two pharmacophores viz., quinazolinone and Mannich bases. In search for new bioactive potent molecule, it was thought worth while to incorporate some additional heterocyclic moieties in the quinazoline nucleus and study their biological and pharmacological activity, the extensive review of literature revealed the compounds have anticancer activity ${ }^{1-4}$. The earliest uses in the pharmaceutical area for quinazoline are anti viral ${ }^{5}$, anti parkinsonism ${ }^{6,7}$ anti microbial ${ }^{8-11}$, anti inflammatory $^{12}$, bronchodilator ${ }^{13}$, anti hypertensive ${ }^{14}$. Encouraged by the above observations from the literature, it was planned to suitably incorporate the Mannich bases in to quinazolinone and to synthesize a better drug with less toxicity to the host, it is observed that chemical modification not only alters physiochemical properties but also pharmacological properties. 


\section{Experimental}

All the chemicals used in the synthesis were of Laboratory grade. The melting points were taken in open capillaries in liquid paraffin and are uncorrected. To monitor the progress of reactions and to establish the identity and purity of reactants and products, thin layer chromatography was performed on aluminium slides coated with silica gel 60, using appropriate solvent systems and the spots were visualized under ultra-violet light. IR spectra were recorded in $\mathrm{KBr}$ on a Shimadzu FTIR 8310 spectrometer. PMR spectrum on AMX 400 (400 MHz) instrument (chemical shift in $\delta \mathrm{ppm}$ ) using TMS as internal standard. Mass spectra were recorded in Shimadzu GC-MSQP5050. The structures of the synthesized compounds were confirmed by spectral analysis.

\section{General procedure for the synthesis of Scheme-1 products}

Step-1: Synthesis of 2-(4-substituted phenyl) quinazolin-4(3H)-one (QZ 1-4)

To the solution of 2-aminobenzamide ( 0.01 moles) and respective $p$-substituted benzaldehyde ( 0.01 moles) in $10 \mathrm{~mL}$ of ethanol, catalytic amount of acetic acid was added. The solution was refluxed and the progress of the reaction was monitored using TLC 15\% ethyl acetate in chloroform (Solvent system: Ethyl acetate-Chloroform: 15:85). After completion of reaction, the reaction mixture was cooled to room temperature and the product obtained was filtered, washed with water and crystallized from absolute ethanol and chloroform (50:50). The physical data of the compounds synthesized were in confirmation with the literature value. The physical data of the compounds synthesized are given in Table 1.

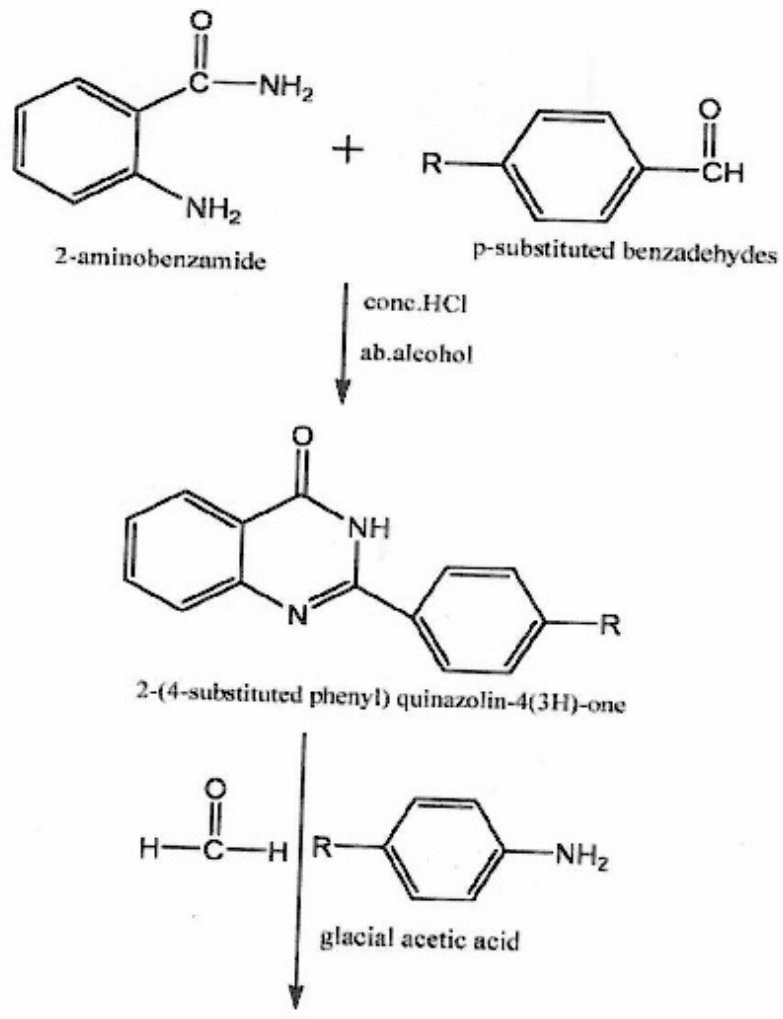




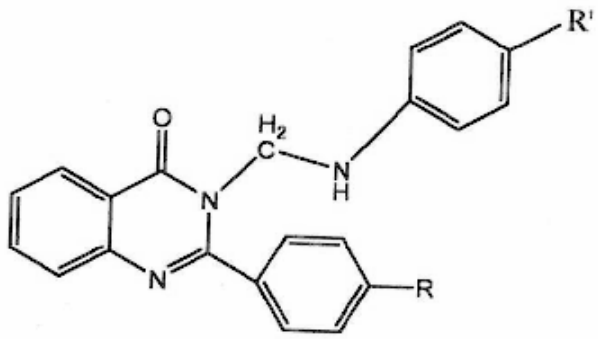

Scheme 1

Table 1. Physicochemical data of synthesized compounds (QZM 1-12)

\begin{tabular}{ccccccc}
\hline $\begin{array}{c}\text { QZ } \\
\text { series }\end{array}$ & Code & $\mathrm{R}$ & $\mathrm{R}^{1}$ & $\mathrm{M} . \mathrm{F}$. & $\mathrm{M} . \mathrm{W}$. & $\mathrm{R}_{\mathrm{f}}$ \\
\hline 1 & QZ1M1 & $-\mathrm{Cl}$ & $-\mathrm{H}$ & $\mathrm{C}_{21} \mathrm{ON}_{3} \mathrm{ClH}_{16}$ & 362 & 0.67 \\
2 & QZ1M2 & $-\mathrm{Cl}$ & $-\mathrm{CH}_{3}$ & $\mathrm{C}_{22} \mathrm{ON}_{3} \mathrm{ClH}_{18}$ & 376 & 0.63 \\
3 & QZ1M3 & $-\mathrm{Cl}$ & $-\mathrm{OCH}_{3}$ & $\mathrm{C}_{22} \mathrm{O}_{2} \mathrm{~N}_{3} \mathrm{ClH}_{18}$ & 392 & 0.65 \\
4 & QZ2M1 & $-\mathrm{F}$ & $-\mathrm{H}$ & $\mathrm{C}_{21} \mathrm{ON}_{3} \mathrm{FH}_{16}$ & 345 & 0.58 \\
5 & QZ2M2 & $-\mathrm{F}$ & $-\mathrm{CH}_{3}$ & $\mathrm{C}_{22} \mathrm{ON}_{3} \mathrm{FH}_{18}$ & 359 & 0.6 \\
6 & QZ2M3 & $-\mathrm{F}$ & $-\mathrm{OCH}$ & $\mathrm{C}_{22} \mathrm{O}_{2} \mathrm{~N}_{3} \mathrm{FH}_{18}$ & 375 & 0.61 \\
7 & QZ3M1 & $-\mathrm{CH}_{3}$ & $-\mathrm{H}$ & $\mathrm{C}_{22} \mathrm{ON}_{3} \mathrm{H}_{19}$ & 341 & 0.61 \\
8 & QZ3M4 & $-\mathrm{CH}_{3}$ & $-\mathrm{p}-\mathrm{Cl}$ & $\mathrm{C}_{22} \mathrm{ON}_{3} \mathrm{ClH}_{18}$ & 376 & 0.65 \\
9 & QZ3M5 & $-\mathrm{CH}_{3}$ & $-\mathrm{p}-\mathrm{Br}$ & $\mathrm{C}_{22} \mathrm{ON}_{3} \mathrm{BrH}_{18}$ & 420 & 0.63 \\
10 & QZ4M1 & $-\mathrm{OCH}_{3}$ & $-\mathrm{H}$ & $\mathrm{C}_{22} \mathrm{O}_{2} \mathrm{~N}_{3} \mathrm{H}_{19}$ & 357 & 0.63 \\
11 & QZ4M4 & $-\mathrm{OCH}_{3}$ & $-\mathrm{p}-\mathrm{Cl}$ & $\mathrm{C}_{22} \mathrm{O}_{2} \mathrm{~N}_{3} \mathrm{ClH}_{18}$ & 392 & 0.65 \\
12 & QZ4M5 & $-\mathrm{OCH}_{3}$ & $-\mathrm{p}-\mathrm{Br}$ & $\mathrm{C}_{22} \mathrm{O}_{2} \mathrm{~N}_{3} \mathrm{BrH}_{18}$ & 436 & 0.63 \\
\hline
\end{tabular}

Step-2: Synthesis of 2-(4-substituted phenyl) 3-[(4-substituted phenyl amino) methyl] quinazolin-4(3H)-one (QZM 1-12)- (Mannich reaction) $)^{15-17}$

To the solution of QZ 1-4 (0.01 moles) and respective $p$-substituted primary amines (0.01 moles) in $5 \mathrm{~mL}$ of glacial acetic acid, formaldehyde solution $30 \%$ (0.05 moles) was added. The solution was refluxed and the progress of the reaction is monitored using TLC Solvent system: Ethyl acetate-chloroform: 15:85. After completion of reaction, the reaction mixture was cooled and immediately poured to crushed ice. The product obtained was filtered, washed with methanol and crystallized from absolute ethanol and chloroform (50:50).

2-(4-Chloro phenyl)-3-[(phenyl amino) methyl] quinazolin-4(3H)-one (QZ1M1)

Yield 95\%; m.p. 240-243 ${ }^{\circ} \mathrm{C}$; IR $\left(\mathrm{KBr}, \mathrm{cm}^{-1}\right)$ : $3429.5(\mathrm{~N}-\mathrm{H}), 1670.2(\mathrm{C}=\mathrm{O}), 761.8(\mathrm{C}-\mathrm{Cl})$; $\mathrm{H}^{1} \mathrm{NMR}\left(\mathrm{CD}_{3} \mathrm{OD}, \partial \mathrm{ppm}\right): 4.97\left(\mathrm{~s}, 2 \mathrm{H},-\mathrm{CH}_{2}\right), 7.1(\mathrm{~m}, 12 \mathrm{H}, \mathrm{Ar}-\mathrm{H}) ; \operatorname{Mass} \operatorname{spectra}(\mathrm{m} / \mathrm{z}): 363$ $(\mathrm{M}+1), 119$ (base peak).

2-(4-Chloro phenyl)-3-[(p-tolyl amino) methyl] quinazolin-4(3H)-one (QZ1M2)

Yield 91\%; m.p. 232-233 ${ }^{\circ} \mathrm{C}$; IR $\left(\mathrm{KBr}, \mathrm{cm}^{-1}\right): 3429.2(\mathrm{NH}$ stretch), 1676.2(C=O), $2852.5(\mathrm{C}-$ $\left.\mathrm{CH}_{3}\right), 761.8(\mathrm{C}-\mathrm{Cl}) ; \mathrm{H}^{1} \mathrm{NMR}\left(\mathrm{CD}_{3} \mathrm{OD}, \partial \mathrm{ppm}\right): 4.97\left(\mathrm{~s}, 2 \mathrm{H},-\mathrm{CH}_{2}\right), 7.1-8(\mathrm{~m}, 12 \mathrm{H}, \mathrm{Ar}-\mathrm{H}), 2.5$ (s, 3H, Ar- $\left.\mathrm{CH}_{3}\right)$; Mass spectra $(\mathrm{m} / \mathrm{z})$ : $377(\mathrm{M}+1), 119$ (base peak).

2-(4-Chloro phenyl)-3-[(p-tolyl amino) methyl] quinazolin-4(3H)-one (QZ1M3)

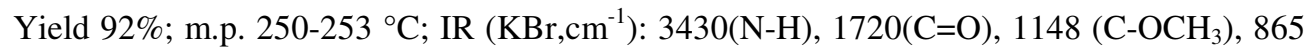
$(\mathrm{C}-\mathrm{Cl}) ; \mathrm{H}^{1} \mathrm{NMR}\left(\mathrm{CD}_{3} \mathrm{OD}, \partial \mathrm{ppm}\right): 3.97\left(\mathrm{~s}, 3 \mathrm{H}, \mathrm{Ar} \mathrm{OCH}_{3}\right), 7.8(\mathrm{~m}, 12 \mathrm{H}, \mathrm{Ar}-\mathrm{H})$; Mass spectra $(\mathrm{m} / \mathrm{z}): 393(\mathrm{M}+1)$. 
2-(4-Fluoro phenyl)-3-[(phenyl amino) methyl] quinazolin-4(3H)-one (QZ2M1) Yield 96\%; m.p. 219-223 ${ }^{\circ} \mathrm{C}$; IR $\left(\mathrm{KBr}, \mathrm{cm}^{-1}\right): 3458.1(\mathrm{~N}-\mathrm{H}), 1670.2(\mathrm{C}=\mathrm{O}), 1147.8(\mathrm{C}-\mathrm{F}) ; \mathrm{H}^{1} \mathrm{NMR}$ $\left(\mathrm{CD}_{3} \mathrm{OD}, \partial \mathrm{ppm}\right): 4.97\left(\mathrm{~s}, 2 \mathrm{H},-\mathrm{CH}_{2}\right), 7.4-8.3(\mathrm{~m}, 13 \mathrm{H}, \mathrm{Ar}-\mathrm{H})$; Mass spectra $(\mathrm{m} / \mathrm{z}): 345(\mathrm{M}+1)$.

2-(4-Fluoro phenyl)-3-[(p-tolyl amino) methyl] quinazolin-4(3H)-one (QZ2M2)

Yield 90\%; m.p. $250-253{ }^{\circ} \mathrm{C}$; IR $\left(\mathrm{KBr}, \mathrm{cm}^{-1}\right): 3425.1(\mathrm{~N}-\mathrm{H}), 1675(\mathrm{C}=\mathrm{O}), 2920\left(\mathrm{C}^{-\mathrm{CH}_{3}}\right)$, 1145.8 (C-F); $\mathrm{H}^{1} \mathrm{NMR}\left(\mathrm{CD}_{3} \mathrm{OD}, \partial \mathrm{ppm}\right): 2.7$ (s, 3H, $\left.\mathrm{Ar}_{-} \mathrm{CH}_{3}\right), 4.9\left(\mathrm{~s}, 2 \mathrm{H},-\mathrm{CH}_{2}\right), 7-8.3$ $(\mathrm{m}, 12 \mathrm{H}, \mathrm{Ar}-\mathrm{H})$; Mass spectra $(\mathrm{m} / \mathrm{z}): 360(\mathrm{M}+1)$.

2-(4-Fluoro phenyl)-3-[(p-methoxy phenyl amino) methyl] quinazolin-4(3H)-one (QZ2M3)

Yield 91\%; m.p. $225-228{ }^{\circ} \mathrm{C}$; IR $\left(\mathrm{KBr}, \mathrm{cm}^{-1}\right): 1725(\mathrm{C}=\mathrm{O}), 3425.1(\mathrm{~N}-\mathrm{H}), 1150\left(\mathrm{C}^{-\mathrm{OCH}_{3}}\right)$, 1140 (C-F); $\mathrm{H}^{1} \mathrm{NMR}\left(\mathrm{CD}_{3} \mathrm{OD}, \partial \mathrm{ppm}\right): 3.7$ (s, 3H, $\left.\mathrm{Ar}-\mathrm{OCH}_{3}\right), 4.9\left(\mathrm{~s}, 2 \mathrm{H},-\mathrm{CH}_{2}\right), 7.7(\mathrm{~m}, 12 \mathrm{H}$, $\operatorname{Ar}-\mathrm{H}) ;$ Mass spectra $(\mathrm{m} / \mathrm{z}): 376(\mathrm{M}+1)$.

3-[(Phenyl amino) methyl]2-p-tolyl quinazolin-4(3H)-one (QZ3M1)

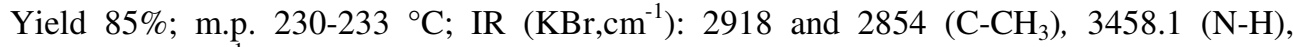
1670.2(C=O); $\mathrm{H}^{1} \mathrm{NMR}\left(\mathrm{CD}_{3} \mathrm{OD}, \partial \mathrm{ppm}\right): 4.97\left(\mathrm{~s}, 2 \mathrm{H},-\mathrm{CH}_{2}\right), 7.4-8.3(\mathrm{~m}, 13 \mathrm{H}, \mathrm{Ar}-\mathrm{H})$; Mass spectra $(\mathrm{m} / \mathrm{z}): 341(\mathrm{M}+1)$.

3-[(4-Chlorophenyl amino) methyl] 2-p-tolyl quinazolin-4(3H)-one (QZ3M4)

Yield 89\%; m.p. $145-148{ }^{\circ} \mathrm{C}$; IR $\left(\mathrm{KBr}, \mathrm{cm}^{-1}\right): 2854\left(\mathrm{C}^{\left.-\mathrm{CH}_{3}\right),} 3458.1(\mathrm{~N}-\mathrm{H}), 1670.2(\mathrm{C}=\mathrm{O})\right.$, 865(C-Cl); $\mathrm{H}^{1}$ NMR $\left(\mathrm{CD}_{3} \mathrm{OD}, \partial \mathrm{ppm}\right): 4.97\left(\mathrm{~s}, 2 \mathrm{H},-\mathrm{CH}_{2}\right), 7.4-8.3(\mathrm{~m}, 13 \mathrm{H}, \mathrm{Ar}-\mathrm{H})$; Mass spectra $(\mathrm{m} / \mathrm{z}): 376(\mathrm{M}+1)$.

3-[(4-Bromo phenyl amino) methyl] 2-p-tolyl quinazolin-4(3H)-one (QZ3M5)

Yield 79\%; m.p. $130-132^{\circ} \mathrm{C}$; IR $\left(\mathrm{KBr}, \mathrm{cm}^{-1}\right): 2918\left(\mathrm{C}^{\left.-\mathrm{CH}_{3}\right),} 3458.1(\mathrm{~N}-\mathrm{H}), 753(\mathrm{C}-\mathrm{Br})\right.$, 1670.2(C=O); $\mathrm{H}^{1} \mathrm{NMR}\left(\mathrm{CD}_{3} \mathrm{OD}, \partial \mathrm{ppm}\right): 4.97\left(\mathrm{~s}, 2 \mathrm{H},-\mathrm{CH}_{2}\right), 7.4-8.3(\mathrm{~m}, 13 \mathrm{H}, \mathrm{Ar}-\mathrm{H})$; Mass spectra $(\mathrm{m} / \mathrm{z}): 420(\mathrm{M}+1)$.

2-(4-Methoxy phenyl)-3-[(phenyl amino) methyl] quinazolin-4(3H)-one (QZ4M1)

Yield 89\%; m.p. $257-259^{\circ} \mathrm{C}$; IR $\left(\mathrm{KBr}, \mathrm{cm}^{-1}\right): 3429.2(\mathrm{~N}-\mathrm{H}), 1681.2(\mathrm{C}=\mathrm{O}), 2360\left(\mathrm{C}_{-} \mathrm{CH}_{3}\right) ; \mathrm{H}^{1} \mathrm{NMR}$ $\left(\mathrm{CD}_{3} \mathrm{OD}, \partial \mathrm{ppm}\right)$ : 4.97(s,2H, $\left.-\mathrm{CH}_{2}\right), 7.4-8.3(\mathrm{~m}, 13 \mathrm{H}, \mathrm{Ar}-\mathrm{H})$; Mass spectra $(\mathrm{m} / \mathrm{z}): 357(\mathrm{M}+1)$.

3-(4-Chloro phenyl amino methyl) -2-(p-methoxy phenyl) quinazolin-4(3H)-one (QZ4M4)

Yield 90\%; m.p. $220-223{ }^{\circ} \mathrm{C}$; IR ( $\left.\mathrm{KBr}, \mathrm{cm}^{-1}\right)$ : 1681.2(C=O), $3429.2(\mathrm{~N}-\mathrm{H}), 847(\mathrm{C}-\mathrm{Cl}), 2360$ $\left(\mathrm{C}-\mathrm{CH}_{3}\right) ; \mathrm{H}^{1} \mathrm{NMR}\left(\mathrm{CD}_{3} \mathrm{OD}, \partial \mathrm{ppm}\right): 4.97\left(\mathrm{~s}, 2 \mathrm{H},-\mathrm{CH}_{2}\right), 7.4-8.3(\mathrm{~m}, 13 \mathrm{H}, \mathrm{Ar}-\mathrm{H})$; Mass spectra $(\mathrm{m} / \mathrm{z}): 392(\mathrm{M}+1)$.

3-(4-Bromo phenyl amino) methyl) -2-(p-methoxy phenyl) quinazolin-4(3H)-one (QZ4M5)

Yield 92\%; m.p. 240-243 ${ }^{\circ} \mathrm{C}$; IR $\left(\mathrm{KBr}, \mathrm{cm}^{-1}\right): 3429.2(\mathrm{~N}-\mathrm{H}), 1681.2(\mathrm{C}=\mathrm{O}), 784(\mathrm{C}-\mathrm{Br}), 2360$ $\left(\mathrm{C}-\mathrm{CH}_{3}\right) ; \mathrm{H}^{1} \mathrm{NMR}\left(\mathrm{CD}_{3} \mathrm{OD}, \partial \mathrm{ppm}\right): 4.97\left(\mathrm{~s}, 2 \mathrm{H},-\mathrm{CH}_{2}\right), 7.4-8.3(\mathrm{~m}, 13 \mathrm{H}, \mathrm{Ar}-\mathrm{H})$; Mass spectra $(\mathrm{m} / \mathrm{z}): 436(\mathrm{M}+1)$.

\section{Results and Discussion}

Anti-tumor activity

Anti-tumor activity was evaluated by two methods viz., Brine shrimp lethality bioassay and Trypan blue exclusion method. 


\section{Brine shrimp lethality bioassay}

This method was developed by Mayer et $a l^{18}$. Drug samples were prepared by dissolving $10 \mathrm{mg}$ of derivative in $10 \mathrm{~mL}$ of ethanol. Nauplli were drawn in a pipette along with water and ten shrimps were transferred to each sample vial after they were counted in the stem of pipette against lighted background. The artificial sea water was added to each vial to make up to $5 \mathrm{~mL}$, a drop of dry yeast suspension ( $3 \mathrm{mg}$ in $5 \mathrm{~mL}$ seawater) was added to each vial as food for shrimps ${ }^{3}$. The vials were maintained under illumination. After 24 hours, survivors were counted by using $3 \mathrm{X}$ magnifying glass and the percent deaths, $\mathrm{ED}_{50}$ values are calculated by using +ve control $\mathrm{K}_{2} \mathrm{Cr}_{2} \mathrm{O}_{7}$ and -ve control ethyl alcohol and the results are shown in Table 2 and Figure 1. Composition of the artificial sea water is given in Table 3.

Table 2. $\mathrm{ED}_{50}$ of synthesized compounds

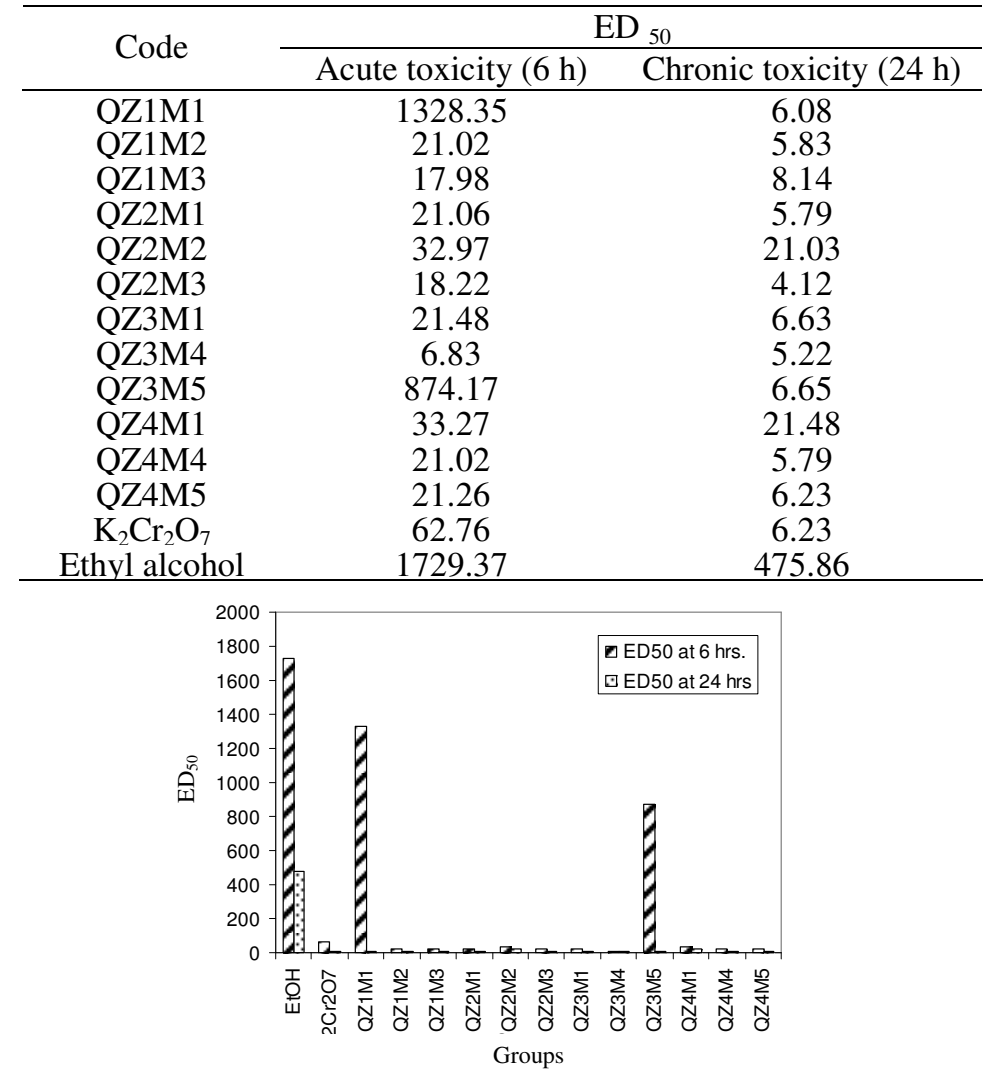

Figure 1. $\mathrm{ED}_{50}$ of synthesized compounds

\section{Tryphan blue exclusion method}

EAC (Ehrlich Ascites Carcinoma) cells were collected by aspiration from animal peritoneum. A suspension of $1 \times 10^{6}$ cells was prepared in phosphate buffer saline (PBS its composition was shown in Table 4) and the viability of the cell was checked by counting with a haemocytometer. DMSO was taken as solvent as solubilizing agent and its concentration was not allowed to go beyond $0.1 \%(\mathrm{v} / \mathrm{v})$ of total volume. Various concentrations of the derivative viz., $10 \mu \mathrm{g}, 25 \mu \mathrm{g}$ and $50 \mu \mathrm{g}$ was taken in a clean test tube added $100 \mu \mathrm{L}$ of the EAC cells 
final volume was adjusted with buffer up to $1 \mathrm{~mL}$ respectively. All the test tubes were incubated at $37{ }^{\circ} \mathrm{C}$ for $3 \mathrm{~h}$ along with control and solvent control. After incubation, $100 \mu \mathrm{L}$ of $4 \%$ tryphan blue was added to each test tube. The alive cells (with out stain) and dead cells (stained) were calculated and checked for the percentage cytotoxicity ${ }^{19}$. The $\%$ cytotoxicity and $\mathrm{IC}_{50}$ of synthesized compounds at different concentrations are given in Table $5 . \mathrm{IC}_{50}$ of synthesized compounds against EAC Cells was graphically represented in Figure 2.

$\%$ Cytotoxicity $=\left(\mathrm{T}_{\text {dead }}-\mathrm{C}_{\text {dead }}\right) / \mathrm{T}_{\text {total }} \times 100$

Where, $\quad \mathrm{T}_{\text {dead }}=$ number of dead cells in the drug treated tube,

$\mathrm{C}_{\text {dead }}=$ number of dead cells in the control tube,

$\mathrm{T}_{\text {total }}=$ number of dead and alive cells in the drug treated tube

Table 3. Composition of the artificial sea water

\begin{tabular}{lc}
\hline \multicolumn{2}{c}{$\begin{array}{c}\text { Composition of artificial sea water } \\
\text { (Modified from morel's Aquil formula) }\end{array}$} \\
\hline \multicolumn{1}{c}{ Components } & $\mathrm{g} / \mathrm{L}$ \\
Sodium chloride LR & 24.0 \\
Calcium chloride LR & 1.5 \\
Potassium bromide LR & 0.1 \\
Potassium chloride LR & 0.7 \\
Sodium sulphate LR & 4.0 \\
Sodium bicarbonate LR & 0.2 \\
Magnesium Chloride LR & 11.0 \\
Total salts & 41.5 \\
\hline
\end{tabular}

The $\mathrm{pH}$ should be adjusted to $\mathrm{pH}$ 7-8 with sodium bicarbonate

Table 4. Composition of the phosphate buffer saline (PBS)

\begin{tabular}{lc}
\hline Ingredients & $\mathrm{g} / 1000 \mathrm{~mL}$ \\
\hline Sodium chloride & $8 \mathrm{~g}$ \\
Potassium chloride & $200 \mathrm{mg}$ \\
Disodium hydrogen phosphate & $1.15 \mathrm{~g}$ \\
Calcium chloride & $100 \mathrm{mg}$ \\
Magnesium sulphate hepta hydrate & $120 \mathrm{mg}$. \\
\hline
\end{tabular}

Table 5. \% Cytotoxicity and $\mathrm{IC}_{50}$ of synthesized compounds at different concentrations

\begin{tabular}{ccccc}
\hline \multirow{2}{*}{ Code } & \multicolumn{3}{c}{$\%$ Cytotoxicity } \\
\cline { 2 - 4 } & $10 \mu \mathrm{g} / \mathrm{mL}$ & $25 \mu \mathrm{g} / \mathrm{mL}$ & $50 \mu \mathrm{g} / \mathrm{mL}$ & $\mathrm{IC}_{50}$ \\
\hline QZ1M1 & 16.58 & 17.88 & 72.91 & 37.87 \\
QZ1M2 & 34.09 & 40.89 & 65.78 & 32.12 \\
QZ1M3 & 19.45 & 75.53 & 62.87 & 25.49 \\
QZ2M1 & 37.28 & 57.14 & 33.59 & 12.62 \\
QZ2M2 & 47.43 & 57.86 & 68.79 & 13.01 \\
QZ2M3 & 25.64 & 40.24 & 79.39 & 19.84 \\
QZ3M1 & 24.45 & 74.19 & 72.60 & 21.75 \\
QZ3M4 & 16.67 & 65.67 & 96.87 & 23.28 \\
QZ3M5 & 15.52 & 75.08 & 90.34 & 22.41 \\
QZ4M1 & 16.93 & 60.77 & 88.09 & 25.25 \\
QZ4M4 & 11.13 & 64.68 & 88.15 & 25.78 \\
QZ4M5 & 17.62 & 60.18 & 91.74 & 24.70 \\
Control (DMSO) & 10.20 & 12.03 & 13.52 & 500.83 \\
Standard drug & 16.28 & 16.2 & 23.53 & 191.16 \\
(Cisplatin) & & &
\end{tabular}




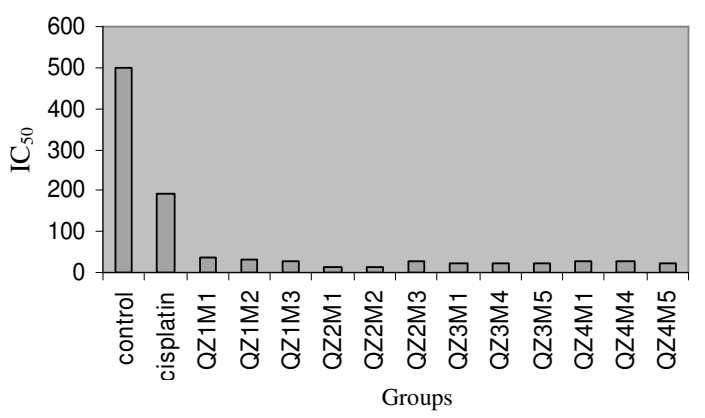

\section{Conclusion}

Figure 2. $\mathrm{IC}_{50}$ of synthesized compounds against EAC cells

The synthesized derivatives were characterized and identified on the basis of physical and spectral data. The derivatives were tested for in vitro cytotoxic potential using brine shrimp lethality bioassay and tryphan blue exclusion method. As the Brine shrimp method is preliminary investigation for the assessment of cytotoxicity, all the synthesized derivatives are screened for this bioassay. $\mathrm{ED}_{50}$ values for the drugs and controls at 50, 100 and $200 \mathrm{ppm}$ concentrations were calculated. $\mathrm{ED}_{50}$ of +ve control $\left(\mathrm{K}_{2} \mathrm{Cr}_{2} \mathrm{O}_{7}\right)$ was found to be $62.76 \& 6.23$ in acute and chronic studies respectively. While $\mathrm{ED}_{50}$ of -ve control (ethyl alcohol) was found to be $1729.37 \& 475.86$ in acute and chronic studies respectively. All the $\mathrm{ED}_{50}$ values of the synthesized drugs were found to be significantly lower than that of -ve control ethyl alcohol and higher than the +ve control $\mathrm{K}_{2} \mathrm{Cr}_{2} \mathrm{O}_{7}$. QZ1M2, QZ2M2, QZ2M3, QZ3M4, QZ3M5, QZ4M4, QZ4M1 and QZ4M5 derivatives were found to have highest cytotoxicity in Brine shrimp lethality Bioassay. Since all the compounds are active, investigation proceeded for tryphan blue exclusion method using EAC cells.

All the synthesized compounds were screened for their cytotoxicity on EAC cells at 10, 25 and $50 \mu \mathrm{g} / \mathrm{mL}$. The tryphan blue exclusion technique indicates that the $\mathrm{IC}_{50}$ of the standard drug cisplatin is 191.16 and that of control was 500.83. All the compounds displayed cell necrosis above $10 \mu \mathrm{g} / \mathrm{mL}$. It reveals that cell necrosis is the main reason for the cell death. In some cases morphological changes in cells were found. It is suspected to be cell apoptosis, which might be the reason for cell death. All the synthesized drugs showed the activity. But promising anti-tumor activity was shown by compounds QZ1M2, QZ2M3, QZ3M4 and QZ4M which might be attributed to the presence of electron with drawing and donating substitution at para or $4^{\text {th }}$ position of the phenyl ring which is at position 2 of quinazolinone ring and in Mannich bases. Thus, the synthesized quinazolinone Mannich compounds containing halogens were more lipophilic than others as per the value. As the compounds are lipophilic in nature they can display good permeability through the phospholipids membranes and so a better activity can be expected.

\section{Acknowledgement}

The authors are thankful to principal and Professor Dr. N. Udupa MCOPS, Manipal University for providing infrastructure and facilities to reinforce research activity and to Indian Institute of Science, Bangalore for providing ${ }^{1} \mathrm{H}$ NMR spectral data.

\section{References}

1. Shah R B, Bhatt J J, Patel H H, Undavia N K, Trivedi P B and Desai N C, Indian J Chem., 1995, 34B, 201. 
2. Gopal M, Shenoy S and Doddamani L S, J Photochemistry Photobiology, 2003, 72(1-3), 69-76.

3. Murugan V, Padmavathy N P, Ramasarma G V S, Sunil sharma V and Suresh B, Indian J Heterocycl Chem., 2003,13, 143-146.

4. Murugan V, Thomas C C, Ramasarma G V S, Kumar E P and Suresh B, Indian J Pharm Sci., 2003,65, 386.

5. Pandey V K, Tusi S and Zehra Tusi, Raghubir R, Dixit M, Joshi M N and Bajpai S K, Indian J Chem Section B: Org Chem Inc Med Chem., 2004, 43(1)B, 180-183.

6. Srivastava V K, Singh S, Gulati A and Shankar K, Indian J Chem., 1987, 26B, 652.

7. Pankaj N, Palit P, Srivastava V K and Shanker K, Indian J Chem., 1989, 28B, 745-750.

8. Saxena K R and Khan M A, Indian J Chem., 1989, 26B, 443.

9. Holla Shivarama B, Padmaja M T, Shivananda M K and Akbarali P M, Indian J Chem., 1998, 37B, 715.

10. Gangwal A N, Kothawade U R, Galande A D, Pharande D S and Dhake A S, Indian J Heterocycl Chem., Indian J Heterocycl Chem., 2001, 10, 291-294.

11. Singh T, Shalabh Sharma, Srivastava V K and Ashok Kumar, Indian J Chem., 2006, 45B, 2558-2565.

12. Tyagi Ritu, Goel Bhawna, Srivastava V K and Kumar A, Indian J Pharm Sci., 1998, 60(5), 283.

13. Raghu Ram A R and Bahekar R H, Indian J Chem., 1999, 38B, 434.

14. Kumar A, Mirdula Tyagi and Srivastava V K, Indian J Chem., 2003, 42B, 21422145.

15. Bhat A R, Gautham Shenoy G and Kotian M, Indian J Heterocycl Chem., 2000, 9, 319.

16. Shirodkar P Y and Vartak Meghana M, Indian J Heterocycl Chem., 2000, 9, 239-240.

17. Verma R S, Agnihotri A K, J Indian Chem Soc., 1979, 56, 162.

18. Meyer B N, Ferrigni N R, Putnam J E, Jacobsen L B, Nichols D E and McLaughlin J L, Planta Med., 1982, 45, 31-34.

19. Eurniss B S, Hannaford A J, Smith P W G and Tatchell A R, Vogel's Textbook of Practical Organic Chemistry, Longman Singapore Publisher Pvt. Ltd., 1996, Edn.5. 